\title{
Eski Türklerde Kut ve Töre Bağlamında Hükümranlığın Hududları
}

\section{Boundaries of Sovereignty in the Context of Kut and Tore in the Old Turks}

\author{
Ali Ahmetbeyoğlu* (1)
}

"Dr. Öğr. Üyesi, İstanbul Üniversitesi, Edebiyat Fakültesi, Tarih Bölümü, İstanbul, Türkiye

ORCID: A.A. 0000-0003-4628-5913

Sorumlu yazar/Corresponding author: Ali Ahmetbeyoğlu,

İstanbul Üniversitesi, Edebiyat Fakültesi,

Tarih Bölümü, İstanbul, Türkiye

E-posta/E-mail: aliahmetbeyoglu@hotmail.com

Başvuru/Submitted: 17.06.2020

Revizyon Talebi/Revision Requested:

23.06.2020

Son Revizyon/Last Revision Received:

08.07.2020

Kabul/Accepted: 13.07 .2020

\section{Atıf/Citation:}

Ahmetbeyoglu, Ali. “Eski Türklerde Kut ve Töre Bağlamında Hükümranlığın Hududları."Tarih Dergisi - Turkish Journal of History, 71 (2020): 29-50.

https://doi.org/10.26650/TurkJHist.2020.003

\section{ÖZ}

Çeşitli kadim devletlerde olduğu gibi, Türk devlet anlayışı da kendine özgü karakteristik bir yapıya sahiptir. Yaşam biçimi ve coğrafi şartlar, diğer devletlerle olan ilişkiler, karşılaştıkları problemler, inandıkları din, mensup oldukları kültür, hukuk anlayışı, değer yargıları ve kâinat algısı Türk devlet düşüncesi ile uygulamalarının temellerini ve sınırlarını oluşturmaktadır. Teşkilatlı boylar halinde yaşayan, sosyal yapılarında toprağa bağlı ayrıcalıklı sınıf bulunmayan, ruhban zümresi olmayan ve tarih sahnesine siyasi teşekkülle çıkan Bozkır Kültüründen neşet eden felsefeyle Türklerin hayatın merkezine ve kâinat algılarına devleti, devletin temeline de Töreyi yerleştirmişlerdir. Hükümdar devletin esas unsurlarından biri olarak onun nitelikleri devletin niteliklerini, yönetimin sınırlarını belirlemiştir. Hükümdar devleti temsil eden ve bir bakıma devlet yerine geçen sembol olarak algılanmıştır. Bu nedenle yürütmenin başında bulunan ve sorumluluğunu taşıyan Hükümdar taşıması gereken niteliklerinde zaaf göstermeye başlar, toplumun ve devleti oluşturan güçler birlikteliğinin beklentilerini karşılayamaz duruma düşer, ülkeyi felaketlere açık hale getirir ise hakimiyeti tartışmalı konuma gelir ve bu durumda Meclis devreye girerek Töreye göre hükümdarlığı sonlandırılırdı.

Anahtar sözcükler: Töre, Meclis, Kut, Hükümdar, Türk Devleti

\section{ABSTRACT}

As in various ancient states, the Turkish state concept has its own characteristic structure. Lifestyle, geographical conditions, relations with other states, problems, belief systems, culture, the understanding of law, practice of values, and perception of the universe set the boundaries and the idea of the Turkish state. Turks did not have a privileged class attached to the land in their social structures or clergy. They lived in organized clans and came onto the stage of history in a political formation. Turks placed their state at the center of life and in their perceptions of the universe, and at the foundation of the state they placed töre (moral laws) with the philosophy that arose from steppe culture. The ruler set the qualifications of the state and the limits of the administration as one of the principal elements of the state. The ruler was perceived as a symbol representing the state and, in a way, as a substitute for the state. Therefore, if the ruler, who bears the responsibility of the executive, begins to show weakness in his qualities, becomes unable to meet the expectations of the unity of society which the forms the state, or makes the country open to disasters, his rule becomes controversial. In this case, the assembly would step in and end his reign according to töre.

Keywords: Töre, Assembly, Kut, Ruler, Turkish State 


\section{Giriş}

Devlet diye adlandırılan ve toplumların sosyal organizasyon ve zekâlarının zirve noktasını teşkil eden kurumun, bir toplulukta bulunup bulunmadığı konusunda yeterli nüfus, yurttaş olma özellikleri, toplumsal düzeni sağlamak için oluşturulan hukuki kuralların uygulanması amacıyla siyasi ve askeri güç varlığı, toplumsal birliği koruma ve bağımsızlık, vergi toplama, siyasi meşruluğun bir dayanağının bulunması gibi çeşitli özellikler aranmıştır ${ }^{1}$. Eski Türk cemiyetinde sosyal yapının en üst kademesini teşkil eden ve Oksızlık (istiklal, bağımsızlık), Uluş (ülke), Kün (halk), Töre (kanun) olmak üzere dört temel unsurdan oluşan “İl”, Willhelm Thomsen'e göre; "siyasî bakımdan bağımsız, muntazam teşkilatlı millet”; R. Giraud'ya göre, "Teşkilatlı devlet, imparatorluk, siyasi hâkimiyet”; G. Clauson'a göre, "Bir müstakil hükümdar tarafından idare edilen siyasi birlik"; A. V. Gabain'e göre, "Ülke, imparatorluk, iktidar veya hükümet” demektir². Kaşgarlı Mahmud İl'e sulh manası vermiştir ${ }^{3}$ ki, devletin fonksiyonuyla yakından alakalıdır.

Çeşitli kadim devletlerde olduğu gibi, Türk devlet anlayışı da kendine özgü karakteristik bir yapıya sahiptir. Yaşam biçimi ve coğrafi şartlar, diğer devletlerle olan ilişkiler, karşılaştıkları problemler, inandıkları din, mensup oldukları kültür, hukuk anlayışı, değer yargıları ve kâinat algısı Türk devlet düşüncesi ile uygulamalarının temellerini ve sınırlarını oluşturmaktadır. Teşkilatlı boylar halinde yaşayan, sosyal yapılarında toprağa bağlı ayrıcalıklı sınıf bulunmayan, ruhban zümresi olmayan ve tarih sahnesine siyasi teşekkülle çıkan Bozkır Kültüründen neşet eden felsefeyle Türkler, hayatın merkezine ve kâinat algılarına devleti, devletin temeline de Töreyi yerleştirmişlerdir. Bu durum Oğuz Kağan Destanı ve Göktürk Abidelerinde açık ifadelerle yansımıştır.

İslam öncesi devirlerde Türkler kâinatın tek hâkimi, tek ve mutlak kudret sahibi, Göktanrı diye adlandırılan bir yüce yaratıcıya inanmaktadırlar. Bu inanç sisteminde Tanrı mefhumu, kâinatın ve hayatın sahibi, düzenleyicisi, ölüm ve hayatın tek sahibi, nimet ve sıkıntıyı veren tek güçtür. O (Tanrı) Bayat (Kadim), Mengü (Baki), Bir (Vâhid), Mungsuz-knedi kendine mevcut ve sıkıntıdan uzak (Muhalefetü'n L'il Hâvadis), Diri (El Hayy), Erkli (İrade sahibi) ve Ogan (Kudret sahibi) olan, Törütgen (el Halik-yaratıcı) ve yarattıklarına hitap eden, konuşan (Kelâm sahibi), Vâcibü'l Vücûd bir varlıktır'. Bu inanç Törenin oluşumu ve yönetimin sınırlarının çizilmesinde ana unsurların başında gelmiştir.

1 A. Bıcak, Türk Düşüncesinin Kökenleri, c. I, Dergah Yayınları, İstanbul 2009, s. 62.

2 İ. Kafesoğlu, Türk Millî Kültürü, Ötüken Neşriyat, İstanbul 1997, s. 233.

3 Kaşgarlı Mahmud, Divanü Lügati 't-Türk, I-IV, çev. B. Atalay, Türk Dil Kurumu Yayınları, Ankara 1939-1941, c. I, s. 48.

4 S. Başer, Kutadgu Bilig'de Kut ve Töre, İrfan Yayınları, İstanbul 2011, s. 15. 


\title{
1. Türk Devlet Düşüncesi ve Oğuz Kağan Destanı
}

Türk devlet düşüncesinin oluşmasında ve gelecek nesillere intikalinde Oğuz Kağan Destanı mühim bir yer tutmuştur. Oğuz Kağan Destanı'nda, Oğuz nezdinde evren tasavvuruna paralel devlet anlayışı kurulmuştur. Destanda Oğuz Türklerin ilk atası olarak kabul edilmiş, icraatlarıyla kendinden sonraki hükümdarlara rol model oluşturmuştur. Ehemmiyeti dolayısıyla da tarih boyunca soyu kutsal addedilmiştir ${ }^{5}$. Kagan kelimesi taşıdığı anlam ile Oğuz'un rol model alındığı ve merkezi bir konumda olduğuna işaret etmiştir'

Oğuz'un fiziki özellikleri, annesini bir kere emdikten sonra bir daha emmemesi, kırk günlük olunca konuşması, beslenmek için çorba ve et istemesi, gençliği döneminde bir ejderhayı öldürmesi ve fiziksel gücü onun normal bir insan olmadığının delilidir ve bu özellikleriyle lider olmayı hak etmiştir ${ }^{7}$. Ayrıca Oğuz'un yaptığı iki evlilik onun lider olacağının göstergesi olarak görülmüştür. İlk evlendiği kız gökten ışık huzmesi içerisinde inmiştir. Bu eşinden Gün, Ay ve Yıldız isimlerinde üç oğlu olmuştur. Çoğu kültürde olduğu gibi Türkler açısından da 1şık, kutsallığ ifade etmektedir. Gökten inen ışık bu bağlamda Tanrıyı temsil ettiğinden, Tanrı Oğuz'un emellerini gerçekleştirmesi için yardım etmiştir. İkinci eşini ise bir göldeki ağaç kovuğunda bulmuştur. Bu eşinden de üç çocuğu olmuştur, isimleri ise Gök, Dağ ve Deniz'dir'. Buradaki göl, ada, ağaç evren modelini ortaya koymaktadır ${ }^{10}$. Türk kozmolojisine göre dünya sular içerisinde yüzen bir kıtadır ${ }^{11}$. Dünya modelini açıklayan su da ağaç da kozmogonideki ifade ettikleri manalar açısından kutsal olarak nitelendirilmiş̧ir. Ateş, su, toprak ve ağaç Türk inancındaki yerlerinden dolayı kutsaldır. İkinci eşini bulduğu ortamda hayatı oluşturan dört öğeden üç tanesi mevcuttur. Su yer gibi ana kabul edilir ve ruhuna dua edilir. Bu bağlamda ikinci karısı yer-suların Oğuz'un amacına hizmet etmek maksadıyla gönderdiği eşidirr ${ }^{12}$.

Bu iki kozmik unsurun birleştiği noktada Oğuz bulunmaktadır. Oğuz, Kaganlı̆̆ını ilan ettikten sonra;

\author{
"Yurdum irmaklarla denizlerle dolsun \\ Gökteki güneş ise yurdun bayrağı olsun \\ İlimiz (Devlet) çadır, yukarıdaki gök olsun \\ Dünya devletim olsun, halkımda çok olsun ${ }^{13}$, demiştir.
}

\footnotetext{
5 Ü. Hassan, Eski Türk Toplumu Üzerine İncelemeler, Alan Yayınc1lık, İstanbul 2000, s. 180.

6 Bicak, aynı eser, s. 66,

7 W. Bang - R. Rahmeti Arat, “Oğuz Kağan Destanı”, yay. haz. Osman Fikri Sertkaya, Makaleler, c. I, Türk Kültürü Araştırmaları Enstitüsü Yayınları, Ankara 1987, s. 614, 616.

8 Bang - Arat, aynı eser, s. 616-618.

9 B. Ögel, Türk Mitolojisi, I, Türk Tarih Kurumu Yayınları, Ankara 1971, s. 117.

10 S. Divitcioğlu, Oğuz'dan Selçukluya Boy, Konat ve Devlet, Eren Yayıncılık, İstanbul 1994, s. 26-27.

11 J. Poul Roux, Türklerin ve Moğolların Eski Dini, Kabalc1 Yayınları, İstanbul 2002, s. 123.

12 Bicak, aynı eser, s. 65.

13 Ögel, aynı eser, s. 118.
} 
Oğuz bu söyledikleriyle bir nevi evren tasavvurunu ortaya koymuştur. Yurdun su ve denizlerle dolu olması, yani bütün ırmak ve denizlere hâkim olmak isteği, su öğesini ön plana çıkartmaktadır. Destanda açıkça bayrak olarak tanımlanan güneş devleti temsil etmektedir. $\mathrm{Bu}$ sebeple dönemin insanının düşüncesinde güneş nasıl dünyanın etrafında dönüyorsa, bayrağında dünyanın etrafında dönecek bir güneşe sahip olması başka bir değişle dünyanın bir bayrak altında toplanması gerekmektedir ${ }^{14}$. Göğün otağ olarak nitelendirilmesi, dünyanın tümünün hükümdarlık altına alınacağının ifadesidir. Gök nasıl dünyayı kuşatıyorsa Oğuz’un kuracağı devlet de dünyayı o şekilde kuşatmalı yani hâkimiyeti altına almalıdı1 ${ }^{15}$.

Oğuz Kağan Destanı'nda bahsedilen dünya devleti lafta kalmamış devamında Oğuz’un yaptığ1 seferler ve kazandığı zaferler sonucunda gerçekleştirilmiştir. Oğuz'un kurduğu dünya devletinde cihan hâkimiyeti temel güçtür. Zira gücü sonucunda dünyaya hâkim olabilmiştir. Oğuz'a dünya hâkimiyetini veren bu gücün iki temeli vardır, bunlardan ilki Tanrı tarafından verilen Kut yani yönetme yetkisidir. Oğuz’un doğuşundaki fiziki tasvir, devamındaki olağan üstü özellikleri Onun Tanrı tarafından seçildiğinin bir göstergesidir. Ayrıca yaptığı iki evlilikle kozmik unsurları birleştirmesi ve kendisinin merkeze oturması da Oğuz'un bu iş için seçildiğini göstermektedir. İkinci unsur ise kazanılan Kut'un korunmasıdır ki, bu kabaca Tanrının emirlerine uymak ve hâkim olduğu toplumun ihtiyaçlarını gidererek adil bir yönetime sahip olmakla mümkündür. Oğuz, destanda topluma kendisini lider olarak kabul ettirmiş ve gayesi uğruna savaştırabilmiştir. Bu durumda Oğuz'un Kut'un ikinci gereğini yerine getirdiği görülmektedir ${ }^{16}$.

Destanın son bölümünde bilge vezir Ulu Türk'ün gördüğü rüya ön plana çıkmakta ve rüyanın konusunu altın yay ile üç gümüş okun doğudan batıya doğru uzanması oluşturmaktadır. Oğuz Han büyük oğullarını yayı, küçük oğullarını ise gümüş okları bulmaları için görevlendirir. Altın yay ile gümüş okları bulan çocuklarına bunları paylaştırmıştır. İlk eşinden olan çocuklar altın yayı almış ve sağ tarafa oturtturulmuşlardır; üç gümüş ok ikinci eşinden olan çocuklara verilmiş ve onlarda sol tarafa oturtturulmuşlardır. Bu durum Türk anlayışının bir parçasıdır. Altın gümüşten daha değerli olduğu için, ayrıca ok’un yay'la atılmasından dolayı Tanrının gönderdiği kızdan olan çocuklar sağ yani kutsal tarafa oturmuşlar; yer-suları temsil eden ikinci eşinden olan çocuklar da yerin göğe bağlı olmasından dolayı sol tarafa oturmuşlardır ${ }^{17}$.

14 S. Koca, “İdeal Bir Türk Hükümdarı ve Baş Komutan Olarak Oğuz Kağan (Oğuz Kağan’ın Türk Tarihi Bakımından Değerlendirmesi)", Büyük Selçuklu Devletinden Türkiye Selçuklu Devletine M. Altay Köymen Armağanı, ed. Mehmet Hacı Gökmen, Selçuk Üniversitesi Türkiyat Araştırmaları Enstitüsü Yayınları, Konya 2011, s. 88.

15 Bicak, aynı eser, s. 67-68.

16 Koca, aynı eser, s.84-85; Bicak, aynı eser, s. 68.

17 Bang-Arat, aynı eser, s. 632-634; H. Şen, İslam Öncesi Türk Inanış ve Düşüncesinde Gök, İstanbul Üniversitesi Sosyal Bilimler Enstitüsü, Yayınlanmamış Yüksek Lisans Tezi, İstanbul 2014, s. 126-127. 


\section{Orhun Abideleri ve Kaganlık/Devlet Anlayışı}

Oğuz Kağan Destanı'nın dışında bizlere eski Türk toplumundaki devlet anlayışını gösterecek ikinci önemli belge muhakkak ki Orhun Abideleridir. Abidelerde Kaganların Tanrı tarafından insanlığı yönetmek için yaratıldığı açık olarak gözükmektedir. "Tanrı gibi (ve) Tanrl'dan olmuş Türk Bilge Kagan”"18, “...üstte mavi gök, altta yağız yer kılındıkta, ikisi arasında insanoğlu kılınmış. İnsanoğlunun üzerine ecdadım Bumın Kagan, İstemi Kagan oturmuş. Oturarak Türk milletinin ilini, töresini tutu vermiş, düzene soku vermiş"19, "Yukarıda Türk tanrısı, Türk mukaddes yeri, suyu öyle tanzim etmiş. Türk milleti yok olmasın diye, millet olsun diye babam İlteriş Kaganı, annem İlbilge Hatunu gögüü tepesinde tutup yukarı kaldırmış olacak..." ${ }^{20}$ ifadeleri bu düşüncenin en güzel yansımasıdır.

Göktürklerin inancına göre üstte mavi gök, altta yağız yer yaratıldığında ikisi arasında kişioğlu yaratılmış, insanlık üzerine Bumin ve İstemi, Kagan olarak gönderilmiştir ${ }^{21}$. İş başına geçen hükümdarları ilk işi yasaları düzenlemek ve bu yasalara göre devleti yönetmekti² ${ }^{22}$ Devletin birinci görevi, toplumun ihtiyacını karşılamak ve toplumun devamını sağlamaktır. Devletin düzenini sağlayacak olan Kaganın görevi ise, devletin hukuki temeli olan Töreyi tesis edip ona riayet etmektir ${ }^{23}$. Devlet kâinat modeline göre oluşturulmalıdır. Ayrıca hükümdar ailesinden olsa bile Kagan olabilmek için Tanrıdan Kut alınmalıdır. Kut'a sahip olmanın şartı da devlete sahip olmak, savaşları kazanıp güçlü bir devlet kurmaktır ki, aksi durumda Kut geri alınırdı ${ }^{24}$. Türk devlet düşüncesinde dirayetli, bilgili ve işin ehli kaganların, komutanların ve devlet adamlarının yetişmemesi halkın devlet ile arasının açılmasına, neticede Kaganın Kut'unu kaybetmesine yol açmıştır. Bu durum Göktürk Abidelerinde düzenin bozulması, devletin çökmesi ya da dağılmasıyla ilişkilendirilmiştir. Çin esareti sırasında çekilen sıkıntılar; “... Illli millet idim, ilim şimdi hani, kime il kazanıyorum der imiş. Kaganlı millet idim, kă̆anım hani, ne kağana işi gücü veriyorum der imiş. Öyle deyip Çin kağanına düşman olmuş. Düşman olup, kendisini tanzim ve tertip edemediğinden yine teslim olmuş." ${ }^{25}$ ifadeleriyle dile getirilmiştir. Halkın esarete isyanı devletin Türkler için ne anlama geldiğinin bir göstergesi olmuştur.

Türk devletinin yeniden kurulması Tanrının izni ve yer-suların yardımıyla gerçekleşmiştir. Devlet toplumun var oluşu için kaçınılmaz olmakla birlikte yapısı Töreye uygun olarak

18 Kül Tigin, Güney Yüzü 1. Satır, M. Ergin, Orhun Âbideleri, Boğaziçi Yayınları, İstanbul 2008, s. 3.

19 Bilge Kagan, Doğu 2-3, s. 33; Kül Tigin, Doğu 1, s. 9.

20 Kül Tigin, Doğu 11, s. 13.

21 Kül Tigin, Doğu 1, s. 9.

22 Bilge Kagan, Doğu 2-3, s. 33.

23 A. Donuk, Eski Türk Devletlerinde İdari-Askeri Unvan ve Terimler, Türk Dünyası Araştırmaları Vakfı Yayınları, İstanbul 1989, s. 42.

24 A. Donuk, aynı eser, s. 38-42.

25 Kül Tigin, Doğu 9 - 10. Satır, s. 11. 
oluşmalıdır. Töreye bağlılık metinlerde: "Devlet kurup Töreyi düzeltmişler"26, "Devletini ve Töreni kim bozabilir" ${ }^{27}$ gibi ifadelerle vurgulanarak, devletin Töresiz yani hukuksuz olamayacağ gösterilmiştir. Ayrıca devleti hak eden dirayetli kişilerin yöneteceği konusunda bizlere Tonyukuk'un şahsında bilgi sunulmaktadır. Tonyukuk, akıllı, bilge, cesur, savaşçı, tecrübeli ve kendinden emin ayrıca en büyük rakibi olan Çinlileri çok iyi tanıyan birisi olarak karşımıza çıkmaktadır ${ }^{28}$. Bu vasıfları taşıyan kişilerin devlet yönetiminde başarılı olacağı belirtilmiştir. Kaganlarla alakalı olarak da Kül Tigin Abidesi'nde "Onlar akıllı (bilge) hükümdar imişler, cesur hükümdar imişler, Komutanları da akıllı imişşüphesiz, cesur imişşüphesiz. Beylerde halk ile barış ve uyum içerisinde imiş şüphesiz, Onun için devleti öylece yönetmişler şüphesiz; devleti yönetip yasaları (Töreyi) düzenlemişler" ${ }^{29}$ demektedir. Bu ifadelere göre cesaret iç karışıklıkları önlemenin yanında dışarıdan gelecek tehlikelere karşı koyabilmek ve iktisadi çıkarları korumak amacıyla savaşabilmek anlamına gelmektedir. Bilgelik Töreyi bilmekle, halkın sorunlarını anlayabilmek ve akıl düzenin sürdürülebilmesi için vazgeçilmez hususlardır ${ }^{30}$.

Abidelerde devletin iç düzenini sağladıktan sonra aynı Oğuz Kağan Destanı'nda olduğu gibi, Tanrı buyurduğu için yayılma harekâtına başlanmış ve Türk Töresini çevre halklara ve dünyaya yaymaya başlamışlardır ${ }^{31}$. Kurulan düzene güvenin ne kadar fazla olduğunu; “Ey Türk, Ŏguz Beyleri ve halkl, işitin! Üstte gök çökmedikçe, altta yer delinmedikçe, ey Türk halkı, senin devletini ve Töreni kim bozabilirdi?"32 satırları göstermektedir. Ayrıca bu satırlar evrenin iki unsuru gök ile yeri devletle ilişkilendirirken, devlet ile toplumsal var oluş arasındaki bağı da ortaya koymaktadır. Esas olan burada toplumsal var oluşun devamlılığını sağlamaktadır. Devletin yok olması milletin yok olması anlamına gelmekle beraber verilen tasvir tıpkı kıyamet gibi de görülmektedir. Yukarıdaki ifadeler aynı zamanda Türklerdeki devletin yok olması toplumun yok olmasina, toplumun yok olması da kiyametin kopmasina sebep olacaktır düşüncesine de işaret etmektedir.

Devletin kurulup genişlemesinde devlet ile özdeşleştirilen Kagan çok önemli bir rol oynamaktadır. İyi Kaganlar döneminde devlet genişlemiş, halk refah ve huzur içerinde yaşamıştır; fakat kifayetsiz Kaganlar döneminde ise devlet çökmeye yüz tutmuş, Tanrı tarafından Kut geri alınmıştır. Çünkü hükümdar Tanrı'nın isteği olan Töreyi tesis edememiştir. $\mathrm{Bu}$ düşünce Abidelerde; "kardeşler ă̆abeyleri, oğullar babaları gibi yaratılmadı̆̆ından, akılsız Kaganlar iş başına gelmiş, yardımcı olarak da akılsız komutanları seçtiklerinden, düzenin bozulmasına neden olmuşlardır" ${ }^{33}$ sözleriyle ifade edilmiştir.

26 Kül Tigin, Doğu 3; Bilge Kagan, Doğu 4, s. 9.

27 Bilge Kagan, Doğu 17, s. 41.

28 R. Girraund, Göktürk İmparatorluğu, çev. İsmail Mangaltepe, Ötüken Neşriyat, İstanbul 1999, s. 114-116.

29 Kül Tigin, Doğu 3, s. 9.

30 A. Donuk, Türk Hükümdarı, Türk Dünyası Araştırmaları Vakfı Yayınları, İstanbul 1990, s. 9, 11.

31 Örnek olarak Kül Tigin, Doğu 1-2. satır verilebilir. Ergin, aynı eser, s. 9.

32 Kül Tigin, Doğu 22; Bilge Kagan, Doğu 18-19. Ergin, aynı eser, s. 17, 41.

33 Bilge Kagan, Doğu 5-6. satır. Ergin, aynı eser, s. 35. 


\section{Kut}

Kut genel bir tarifle siyasi iktidar anlamındadır ${ }^{34}$. Yani Türk hükümdarına yönetme hakkının Tanrı tarafından verilmesi olarak isimlendirilebilir. Oğuz Kağan Destanı'na göre Oğuz Han hem karizmatik bir kimsedir hem de hâkimiyeti ilâhî bir menşeden almıştır. Bu telakki aynı zamanda Orhun Abidelerine ve diğer kaynaklara da yansımıştır. Yönetme hakkı hükümdara Tanrı tarafından ilâhî bir lütuf olarak verilmiştir. Kagan, Tanrı irade ettiği, kendisine Kut (devlet, baht, iyilik, talih) ve ülüğ (kısmet) verdiği için idare etme hakkına sahiptir. Türk Kaganı âdeta göğün, Tanrının yeryüzündeki halifesi-temsilcisi gibidir. Nitekim Asya Hun Devleti Tanhu'su Mo-tun'un unvanı “Göktanrı'nın tahta çıkarttığı Tanrı Kut'u Tanhu” ${ }^{35}$ idi. Hsia Hun Devleti Tanhu'su Hê-lien Po Po (5. asrın ilk çeyreği) “Benim hükümdar olmam Tanrı tarafindan kararlaştırıldı"36 demiştir. Bunun benzer örneği Avrupalıların Attila'yı Tanrının kılıcı olarak görmeleri gösterilebilir. Göktürk Kaganları bizlere bıraktıkları Abidelerde "Tanrl gibi gökte olmuş Türk bilge Kaganı"37, "Tanrı buyurduğu için, Kut'um olduğu için Kagan oldum" demişlerdir ${ }^{38}$. Uygur hükümdarı da Gazneli hükümdarı Sultan Mahmud'a 1027 yılında yazdığı mektuba; “Göklerin sahibi Tanrl, yeryüzü ülkelerinin ve birçok kavmin hâkimiyetini bizlere verdi" diye başlamıştır ${ }^{39}$. Bu ifadeler Türk hükümdarlarının Kut ve kısmetle donatıldığına inandıklarını göstermektedir.

Türk hükümdarının Tanrı ile olan bağı şeklinde de görebileceğimiz, başka bir deyişle devleti temsil eden Kaganın Tanrıyla alakası olarak adlandırabileceğimiz bu Kut sayesinde Tanrı Türk devletine doğrudan etki edebilmektedir. İslam öncesi dönemde Türk devletinin temel ve karakteristik özelliği olan merkezi otorite unsuru doğrudan Tanrı ile alakalıdır. Kagan, ancak Tanrı'nın onaması ve desteği ile Kagan olabiliyordu. Bu durum Göktürk Abidelerinde Bilge Kagan'ın tahta geçmesi ve başarısı "Tanrı Kut verdiği için" ${ }^{40}$ şeklinde açıklanmaktadır.

Aynı anlayış Uygur Kaganlarının unvanlarında da görülmektedir. Ay Tengri’de Kut Bulmuş Alp Külüg Bilge Kagan, Ay Tengri’de Ülüg Bulmuş Alp Uluğ Bilge Kagan, Ay Tengri’de Kut Bulmuş Bilge Kagan gibi ${ }^{41}$. Tuna Bulgarları da hâkimiyetin Tanrı menşeli olduğuna inanmış ve bu

34 İ. Kafesoğlu, Türk Millî Kültürü, s. 248; S. Gömeç, Türk Kültürünün Ana Hatları, Akçağ Yayınları, Ankara 2006, s. 39. A. Donuk, "Türk Devletinde Hakimiyet Anlayışı" isimli makalesinde bu konuda en derli toplu bilgiyi sunmakta ve çeşitli araştırmacıların fikirlerini belirtmektedir. Detaylı bilgi için bakınız A. Donuk, "Türk Devletinde Hâkimiyet Anlayışı”, Tarih Enstitüsü Dergisi, sayı X-XI, İstanbul 1979-1980, s. 51, dipnot 120, İstanbul 1981; ayn.yzr., Eski Türk Devletlerinde İdari-Askeri Unvan ve Terimler, s. 78-79.

35 Kafesoğlu, aynı eser, s. 248-49.; Donuk, Eski Türk Devletlerinde Unvan ve Terimler, s. 77-78.

36 Kafesoğlu, aynı eser, s. 249; Donuk, "Türk Devletlerinde Hakimiyet Anlayışı", s. 49; M. Niyazi, Türk Devlet Felsefesi, Ötüken Neşriyat, İstanbul 2011, s. 45-46.

37 Kül Tigin, Güney 1. Ergin, aynı eser, s. 3.

38 Bilge Kagan, Kuzey 7. Ergin, aynı eser, s. 59.

39 O. Turan, Türk Cihân Hâkimiyeti Mefkûresi Tarihi, Ötüken Neşriyat, İstanbul 2006, s. 168.

40 Kül Tigin, Doğu Cephesi, 29. Satır. Ergin, aynı eser, s. 18-19.

41 D. Hocaoğlu, Türk Kozmolojisi, Yayınlanmamış Doktora Tezi, Basılmamış Doktora Tezi, İstanbul Üniversitesi Sosyal Bilimler Enstitüsü, İstanbul 1994, s. 112; Donuk, Eski Türk Devletlerinde Unvan ve Terimler, s. 78; G. Çandarlığlu, Uygur Devletleri Tarihi ve Kültürü, Türk Dünyası Araştırmaları Vakfı, İstanbul 2004, s. 24-32. 
durumu diktikleri Abidelerde dile getirmişlerdir. Krum Han Kitabesinde Tervel Han'ın “'Bulgarlar üzerine Tanr tarafindan getirildiği”, Malamir Kitabesinde "Tanriya benzer Tanrı tarafindan tahta çıkarılmış Malamir", Çatalar Yazıtı'nda “Yeryüzünde Tanrı tarafından tahta çıkarılmış Han Omurtag” ifadeleri yer almaktadır ${ }^{42}$. Selçuklu Sultanı Sencer 1133 senesinde Abbasi Halifesine gönderdiği bir mektupta, Ulu Tanrının lütfu ile Cihân Padişahlığına yükseldiğini ifade etmiştir. Hâkimiyetin kendisine Allah tarafından verildiğine inanan Sultan Alparslan da Tanrının kendisine teveccüh gösterdiğini, âdemoğulları arasında dünya işlerini nizama koyması için seçildiğini ifade ederek; "zamanın çehresini fikirlerin nuru ile aydınlatmış, dünya yüzünü devletin büyüklüğü ve adaleti ile süslemiş, devlet merdivenlerini çıkmamı emretmiştir" demiştir ${ }^{43}$.

Göktürk alfabesiyle yazılıp günümüze kadar ulaşan Irk Bitig adlı fal kitabında görüldüğü üzere, bir insan Tanrı'yı yücelterek ve saygıyla niyaz ederek Kut isteyebilmektedir. Tanrı da bu niyazı geri çevirmeyerek isteyene Kut ve sürüler veriyor, uzun ömürler bağışlıyordu4 Bu bilgiden anlaşıldığı üzere Kut Tanrı tarafından verilmektedir. Kaynaklardan öğrenildiğine göre Tanrı'nın kendisine Kut ve saadet verdiği kulun işi her gün yükselirdi" ${ }^{45}$ Tanrı kime destek ve yardımda bulunursa o kul Kut bulurdu ${ }^{46}$. Tanrı kime inayet ve yardım ederse dünya onun olur ${ }^{47}$. Kut Tanrı'nın fazlıdır ${ }^{48}$. Kut'u yükselten de O (Tanrı) idi' ${ }^{49}$. Kut'un güçlenmesinin bir diğer sebebi de halkın hayır duasıdır ${ }^{50}$. Verilen bu Kut daimi değildir. Belli durumlarda Tanrı Kut'u verdiği kişiden alabilmektedir. Bey’in (Hükümdarın) gönlü, dili ve tabiatı düzgün olmazsa Kut o memlekette dolaşmaz, kaçard $1^{51}$. Hükümdarların Töreye uymaları gerekmektedir, zira Kagan uyarsa halk da Töreye riayet ederdii ${ }^{52}$. Eğer Kagan Töreye riayet etmezse Tanrı Kut'u kendisinden alır, o kişiyi zillete düşürür ve alçaltırdı. Mesela Töreye göre Kaganlık Bilge Kagan'ın hakkı iken, onun yerine geçmeye çalışan İnel Kagan, Tanrının verdiği Kut'u toparlayamaması sebebiyle tahtından olmuş ve Töreye uymadığı gerekçesiyle öldürülmüş̧ür ${ }^{53}$. Ibni Batuta Seyahatnamesi'nde Türklerin yılda bir kere toplanarak Kaganın Töreye uygun hareket edip etmediğini kontrol ettiklerini, gerekirse Kaganın düşürülebileceğini belirtmiştir ${ }^{54}$. Bunlar bizlere zorbalık ile Törenin bir arada bulunmayacağını göstermektedir.

42 A. Ahmetbeyoğlu, "Tuna Bulgar Hükümdarı Malamir (831-836) Han”, Prof. Dr. Ísmail Aka Armăganı, ed. Nejdet Bilgi ve Mehmet Ersan, Beta Basım, İzmir 1999, s. 217-218.

43 Kafesoğlu, aynı eser, s. 364; M. A. Köymen, Alp Arslan ve Zamanı, II, A.Ü. Dil Tarih Coğrafya Fakültesi Yayınları, Ankara 1983, s. 4.

44 H. Namık Orkun, Eski Türk Yazıtlarl, Irk Bitig, c. III, TDK Yayınları, İstanbul 1940, Paragraf 47.

45 Kaşgarlı Mahmud, Divanü Lügati 't-Türk, I-IV, çev. B. Atalay, Türk Dil Kurumu Yayınları, Ankara 1939-1941, c. I, s. 320 .

46 Yusuf Has Hacib, Kutadgu Bilig, çev. R. R. Arat, TTK Basımevi, Ankara 1985, Beyit: 1267-68.

47 K.B. Beyit: 6192.

48 K.B. Beyit: 6193.

49 K.B. Beyit: 1258.

50 K.B. Beyit: 6424.

51 K.B. Beyit: 2012.

52 K.B. Beyit: 2111.

53 Orhun Abideleri, Bilge Kagan, Doğu Cephesi 29. Satır; Niyazi, aynı eser, s. 48; İ. Kafesoğlu, Kutadgu Bilig ve Kültür Tarihimizdeki Yeri, Kültür Bakanlığı Yayınları, İstanbul 1970, s. 23.

54 O. Turan, Selçuklu Tarihi ve Türk İslâm Medeniyeti, Turan Neşriyat Yurdu, İstanbul 1969, s. 40; Niyazi, aynı eser, s. 60. 
Bu konuda DLT'de "Zor Kapıdan girerse Töre bacadan çıkar" 55 denilmektedir. Türk toplumu için Töre o kadar önemlidir ki devletsiz olunur fakat Töresiz olunamazd $1^{56}$.

Kut, Tanrı'nın bağışı idi. Devlet yönetimi için devleti yönetme yetkisinin bir kişiye verilmesi olarak ifade edilmektedir; fakat hükümdarlık, yönetme yetkisi Töre ile sınırlandırılmıştır ${ }^{57}$. Daha açık bir ifade ile Tanrı, Türk Kaganını ancak Türk Töresini yürütmeleri için tahta çıkartmaktaydı. Kaganlar hakimiyeti Töreye göre kullanırlardı. Yusuf Has Hacib, Karahanlılar ve Gazneliler dönemi Türk hâkimiyet telakkisini en belirgin şekilde yansıtan Kutadgu Bilig'de; yöneticilerin kanun (öngdi) ve Töreye uymaları gerektiğini, böylece halkın da uyacağını belirtmiştir. Yusuf Has Hacib “Ĕ̆ger (Törenin tatbikinde) kusur edersen Tanrı'dan affını dile", diyerek Töreyi hatalı uygulayanları ikaz etmiştir. Bu bakımdan Türk hükümdarının despotik bir saltanat sürmesi mümkün değildir ${ }^{58}$. Kagana yönetme yetkisini verse de Töre tarafından sınırlandırılan bu Kut'un bazı özellikleri bulunmaktadır. Mesela Kut'un tabiatı kararsızdır, Kut alınca emniyet hissine kapılmak yanlıştır. O gelir gider dünyayı dolaşır, kendisine sabit bir yurt yoktur. Fakat onu bir yerde tutacak olan da alçak gönüllülüktür ${ }^{59}$. Kut'un tabiatı yumuşaktır, yaşı küçüktür. Bütün bey ve büyüklere giden yol ondan geçer. Yine o, her türlü büyüklügüun kaynağıdır ${ }^{60}$. Kut insandaki asıl cevherdir. Kut insanın bir nevi otonom kudretidir. Bir nevi nefis kontrolüdür. Kut hizmet amaciyla kapıda beklemektir ${ }^{61}$. Kut'un özelliklerini daha da çoğaltmak mümkündür. Bunun dişında Kut kazanmak için kendi özüne, nefsine sahip olmak gerekmektedir. Kut alçak gönüllü kişiye verilmektedir. Kut güler yüzlü tatlı dilli olanı sever, ona gider ${ }^{62}$. Kut'un kendisi temizdir, temizlik arar, ancak saf olanı destekler ${ }^{63}$. Kut adaletli olanı tercih eder, s1k1 bir terbiyeden geçene Kut verilir, büyügünü büyük tutana, kanaatkâr ve rıza sahiplerine Kut verilmektedir ${ }^{64}$. Bunun durumların tersi söz konusu olunca yani kötü bir insan olunca da Kut kaçmaktadır.

\section{Töre ve Devletin Fonksiyonları}

Kut'un uygulanmasında vazgeçilmez unsurlardan birisi olarak gösterilen, Tabgaçlardan beri bilinen ve esas söyleniş şekli “törö” olan Töre (Törüğ); Türk devletinin ve toplumunun siyasi ve sosyal hayatını tanzim eden sözlü hukuk kurallarının tümüne verilen isimdir ${ }^{65}$.

55 D.L.T. C.II s. 17 vd.

56 D.L.T. C.II s. $17 \mathrm{vd}$.

57 Kafesoğlu, Türk Milli Kültürü, s. 250.

58 K.B. Beyit: 1458, 2111; Hocaoğlu, aynı eser, s. 16.

59 Başer, Kutadgu Bilig'de Kut ve Töre, s. 83.

60 K.B. Beyit: 674-675.

61 Başer, aynı eser, s. 84-85.

62 K.B. Beyit: 2649, 2764, 2478, 163.

63 K.B. Beyit: 2105.

64 Başer, aynı eser, s. 91-92.

65 A. Donuk, Eski Türklerde Devlet ve Teşkilatı, Yayınlanmamış Doktora Tezi, İstanbul Üniversitesi 1978, s. 85;

E. Güngör, Tarihte Türkler, Ötüken Neşriyat, İstanbul 2003, s. 12. 
Töre kelimesi türe kökünden gelmektedir ve türetmek anlamındadır. Orhun Abidelerinde Töre on bir yerde geçmiş ve altısında İl (devlet) ile birlikte yer almıştır. Zira Türklerde devletin varlığı Törenin varlığıyla sıkı sıkıya bağlıydı. Kaşgarlı Mahmud Töreyi düzen, nizam, görenek, âdet yerine kullanmıştır. DLT'de Töre kelimesi beş ayrı yerde geçmektedir. Bunlardan biri madde başı, diğerleri ise başka maddelerin açıklanması sırasında verilen örneklerde zikredilmiştir. Törü: Töre. Atalardan kalan yazılı olmayan kaideler. Il gider, Töre kalır. Zulüm kapıdan girince Töre bacadan çıkar. İ barışa (Töreye) kavuşsun. İ terk edilir, âdet (Töre) terkedilmez. Kaşgarlı, Töreyi Arapça resm (usul, kural, düzenleme) kelimesiyle izah etmiştir. Ayrıca âdet, gelenek ile de açıklamıştır. Töre göğü ayakta tutan sistemdir, o bozulursa kâinat bozulur. Bu kelime bir bakıma İlahi nizam olarak adlandırılabilir zira Tanrı yarattı̆̆ 1 her şeye yetmektedir ${ }^{66}$.

Töre üç şekilde teşekkül ederdi. Birincisi Kagan veya Boy Beyi yahut Bodun idarecisinin buyruklarının hukuk oluşturmasıydı. Orhun Abidelerinde Türk halkını derleyip toplayan ve aynı siyasi yapı içerisinde birleştiren Ulu Kaganın yaptığı işlerin en önemlilerinden birisinin kanun yapmak olduğu belirtilmiştir. Bu konuyu Yusuf Has Hacib şöyle açıklamıştır; "Hükümdarlı uludur, çok iyidir fakat daha iyi olan Töredir. Fakat bundan da iyi olan Törenin tüz (eşit) tatbik edilmesidir". Hangi hükümdar devletine kanun koydu ise, o devletini tanzim etmiş olurdu. "Halka hep iyi kanunlar tatbik edilmelidir". "Ey hükümdar iyi kanun yap...Kanuna kendin riayet et ki, halk da sana itaat etsin" ${ }^{67}$. Hukukun oluşmasında ikinci yol kimi kanun ve kuralların kurultaylarda alınan kararlarla oluşmasıydı. Üçüncü yol da örf ve âdetlerin hukuku yani Töreyi meydana getirmesiydi. Özellikle aile ve miras hukuku, ticaret hukuku alanında Türk toplumunda örf ve âdetler belirleyici rol oynamıştır. Örf ve âdet hukukunun köklü yapısı sayesinde fazla sarsıntı geçirmeden bir siyasi yapıdan diğerine intikal edebilmiştir. DLT'de geçen “Il gider, Töre kalır” Türk atasözü, Boydan başlayarak devlete kadar Türk siyasi teşekküllerinden daha fazla belirleyici olanın hukuki esaslar olduğunu ortaya koymaktadır. Müslüman Selçuklularda da İslam hukukunun yanı sıra ihtiyaç duyuldukça oluşturulan hukuk, İslam âlimlerinin içtihatlarıyla değil tam tersine hükümdarların emir ve fermanlarıyla meydana gelmiştir. Oluşum şeklinin farklılığı sebebiyle de ayrı bir isimle anılmış ve örfi hukuk denilmiştir ${ }^{68}$.

66 DLT. I, s. 18,106; II, s.25; III, s. 221; Başer, aynı eser, s. 112-113; D. Düzgün, “Divanü Lügati't-Türk’te Sosyal Normları Karşılayan Kavramlar”, A. ̈. Türkiyat Araştırmaları Enstitüsü Dergisi, sayı 55, Ankara 2007, s. 203-207.

67 K.B. Beyit: 2029, 2713, 4013, 5196, 5252.

68 K.B. Beyit: 453-455; M. Akif Aydın, “Türk Hukuk Tarihinde Devlet ve Hukuk”, I. Türk Tarihi Sempozyumu, Türklerde Devlet Bildiriler, ed. Hayrunisa Alan, Ali Ahmetbeyoğlu, Uğur Demir, Adnan Baycar, Seçil Ofset, İstanbul 2018, s. 47-51; S. Uğurlu - K. Yılmaz, “Türk Devlet Yönetme Geleneğinde Töre'den Örf’e Değişim”, Turkish Studies, sayı 6/2, 2011, s. 954-955; E. Yakut, "Eski Türklerde Hukuk”, Anadolu Üniversitesi Edebiyat Fakültesi Dergisi, 1 (3), Ankara 2002, s. 414-415; S. Maksudi Arsal, Türk Tarihi ve Hukuk, İstanbul Üniversitesi Hukuk Fakültesi Yayınları, İstanbul 1947, s. 206, 261, 286; M. Akif Aydın, Türk Hukuk Tarihi, s. 15; H. Cin - A. Akgündüz, Türk Hukuk Tarihi, Selçuk Üniversitesi Basımevi, Konya 1989, s. 34, 43; İbn Fazlan, Seyahatname, haz. R. Şeşen, Bedir Yayınları, İstanbul 1995, s. 116. 
Devlet düzenini sağlamakta uygulanması gereken temel unsur Töredir. Töre, geleneklerde ortaya çıkan ve uyulması zorunlu olan değerler bütünü ${ }^{69}$, yani hukuktur. Her kurum ve sosyal eylem kendi geleneğini meydana getirdiğinden, bu geleneklerin dayandığı ilkeler Töreyi oluşturmaktaydı. Ayrıca yılda iki defa toplanan kurultaylar ve hükümdarların aldıkları kararlar da Töre dediğimiz geleneklere dayanmaktaydı. Kişi ve kurumların gerçekleştirdikleri eylemler Töreye uymak zorundayd, aksi takdirde cezai işleme maruz kalarak cezalandırırlardı. Bu bakımdan Törenin bir bağlayıcılığı ve yaptırım gücü bulunmaktaydı. Töre kişiye bakılmaksızın -ister hükümdar olsun, isterse sıradan insan- uygulanmıştır. Töre geleneklerden meydana geldiğinden, toplumun da bu gelenekleri bilmesinden dolayı yöneticilerin Töreye uyup uymadıkları halk tarafından kolaylıkla denetlenebilmiştir. Törenin en temel amacı kişisel hak ve özgürlükleri güvence altına alarak, devletin adalet yönünde işlemesini sağlamaktı. Böylece kişi kendini güvende hisseder ve kendini güvende hisseden kişi Töreye ve Törenin uygulayıcısı hükmündeki hükümdar ve devlete sıkı sıkıya bağlı hale gelirdi. Bu durum toplumsal birliği arttırır ve toplumsal birlik toplumsal varoluşu sağlardı. Kişisel özgürlüklerden başlayarak toplumsal varoluşun sağlanmasında temel şart olan Töre, devlet eliyle gerçekleştirildiğinden insanların devlete aidiyeti sağlanırdı.

Karizmatik olduğunu bildiğimiz hükümdar Tanrıdan aldığı güç ile Türk devlet düşüncesinde mutlak otorite sahibi, despot bir yapıya bürünmemiştir. Bunun temel sebeplerinden birisi olarak Kut ve Töreyi gösterebiliriz. Zira Kut hükümdara halkı yönetmesi maksadıyla verilmiştir. Tanrının istekleri yerine getirilmez ise bu yetki geri alınarak başkasına devredilmiştir. Öte yandan Türk toplumunda bir Töre yapısının bulunması ve herkesin bu yapıya riayet etmek zorunda kalması, Töre önünde Kagan ile halkın ayrılmadan işledikleri suça göre cezaya tâbi tutulmaları diktatörlüğü engellemiştir. Törenin tarihi süreçte hâkimiyet hakkına müdahale edişi fiiliyatta Kaganı sınırladığını göstermiştir ${ }^{70}$. Nitekim Göktürk Kaganlarından Ta-po (581)'nun istişare etmeden yerine Talo-pien'i varis bırakması devlet meclisince Töreye uygun bulunmayarak reddedilmiştir ${ }^{71}$. Bu durum hükümdarın her ne kadar karizmatik bir hüviyete sahip olsa da devlet işleri açısından danışmaya ve Töreye verilen önemi ortaya koymakta, gerektiğinde hükümdarın kararlarının iptal edebileceğini göstermektedir. Hatta istişare meclisi olarak gösterebileceğimiz meclisin, Kut’u toplayamadı diyerek hükümdarı uzaklaştırdığı bilinmektedir. Hazarlarda ise akıl melekelerini yitireceği düşüncesiyle hükümdarların kırk yıldan fazla görev yapamaması ${ }^{72}$ hükümdarın sonsuz

69 Orkun, Eski Türk Yazıtları, s. 117; A. Caferoğlu, Eski Uygur Türkçesi Sözlüğü, Türk Dil Kurumu Yayınları, İstanbul 1968, s. 250.

70 H. İnalcık, "Kutadgu Bilig'de Türk ve İran Siyaset ve Nazariye ve Gelenekleri”, Reşit Rahmeti Arat Için, Türk Kültürünü Araştırma Enstitüsü, Ankara 1966, s. 266; N. G. Ergan, "Bozkır Türklerinde Töre ve Sosyal Kontrol”, Polis Bilimleri Dergisi, cilt I, sayı 3, s. 5-6; Hocaoğlu, Türk Kozmolojisi, s. 16.

71 A. Taşağıl, Gök-Türkler, T.T.K. Yayınları, Ankara 1995, s. 34.

72 Mesudî, Murûc ez-Zeheb, çev. A. Batur, Selenge Yayınları, İstanbul 2004, s. 72; İbn Fazlan, Seyahatnâme, s. $80-81,123$. 
yetkiye sahip olmadığını göstermiştir. Türk hükümdarı Tanrının yeryüzündeki temsilcisi olmakla beraber hiçbir zaman Tanrı özelliği taşımamıştır. Tanrı, görevini başarması için hükümdara sadece ferdi yetenek ve üstünlük bahşetmiştir. İslam devletinde de devlet başkanının yetkilerini Allah'ın rızasına uygun kullanması gerekirdi. Tasarrufları naslara aykırı olmamalıdır. Naslara aykırı tasarruflarda bulunur, nasların düzenlemediği sahalarda adaletten saparsa dünyada ve ahirette müeyyidelerle karşılaşırd1 ${ }^{73}$.

Kut ile Töre arasında güneş ile ay arasındaki bağlantı vardır. Burada ay Kut'u, güneş ise Töreyi temsil etmektedir. Ay güneşten 1 şı alarak gece kendini gösterdiği gibi Kut da Töreden beslenmektedir. Bunların dışında Töre ve Kut'un uygulanabilmesi adalet ve irfan ile gerçekleşirdi. Bunun yanında Eski Türk hâkimiyet telakkisi siyasi iktidarın kaynağını Tanrıya bağlamakla hükümdarı Tanrı katında sorumlu tutuyordu. Hükümdar da Tanrıya karşı sorumlu olduğundan, Tanrının yardımı ile Kut'unun devam edeceğine inandığından, onun iradesine uygun şekilde milleti yönetmek mecburiyetinde hissediyordu. Tanrıya uyması da gerekiyordu. Töre yoluyla idareci altındakilere karşı sorumlu bulunduğundan, Türk hükümdarlarının insafsız, müstebit olmaları pek mümkün değildi.

Kozmolojik olarak Tanrının yeryüzündeki sembolleri dağ, ağaç ve Kagandır. Bu bakımdan tıpkı Oğuz Kağan Destanı'nda olduğu gibi hükümdar kozmik düzenin merkezindedir. İnanç sisteminde hükümdarın en önemli özelliği Tanrı tarafından seçilmiş olmasıdır. Dolayısıyla hükümdarın Tanrı ile olan ilişkisi tüm toplumu ilgilendirmektedir. O cezalandırılırsa bütün toplum cezalandırılmakta, lütfa mazhar olursa bütün halk bundan nasiplendirilmektedir. Ayrıca topluma karşı en önemli vazifelerinin başında da Tanrı ile toplum arasındaki ilişkileri düzenlemek gelmektedir ${ }^{74}$.

Hükümdar devletin esas unsurlarından biri olduğundan onun nitelikleri devletin niteliklerini, yönetimin sınırlarını belirlemiştir. Hükümdar devleti temsil eden ve bir bakıma devlet yerine geçen semboldür ${ }^{75}$.

Oğuz Kağan Destanı'nda ve Göktürk Abidelerinde tespit edilebilen kâinat tasavvuru ile Türk devlet anlayışı arasındaki benzerlik, cihanşümul Türk devlet anlayışının, toplumsal düzen ile evrensel düzenin birleşmesinin bir sonucu olarak ortaya çıktığını göstermektedir. Toplumsal düzeni oluşturan unsurlar ahlak ilkeleri, iktisadi yapı, yaşayış biçimi, inanç sistemi ve Töredir. Devlet bu ilkelerin her biri ile uyum içerisinde yapılandığından söz konusu ilkeleri kendi bünyesinde barındırır. Bu bakımdan toplumsal düzeni oluşturan ilkeler toplumun tamamı için sağlanmalıdır ve devlet bu işlemi gerçekleştirmekle yükümlüdür. Bu babda hükümdar ve devlet ricali Töre adı verilen hukuki düzeni uygulamak ve bu hukuki düzene

73 Niyazi, aynı eser, s. $60 \mathrm{vd}$.

74 Bicak, aynı eser, c. I, s. 80.

75 Giraund, Göktürk Imparatorluğu, s. 114-115. 
uymak zorundadır. Aksi takdirde ise siyasi meşruiyetini kaybederek cezalandırılmaktadır. Öte yandan devlet toplumsal düzene uymak zorunda olduğu kadar evrensel düzene de uymalıdır. Bunun başlıca nedeni ise hükümdarın yönetme yetkisini Tanrıdan almasıdır. Türklerin inancına göre devlet, hükümdara Tanrı'nın bir bağışıdır ${ }^{76}$.

Hülasa olarak Türk düşüncesinde devlet hükümdarın şahsında temsil edildiğinden, hükümdarın Tanrı ile olan ilişkisi devleti de bağlamaktadır. Bu durum en açık ifadesi Göktürk Abidelerinde yer alan hükümdarın Tanrı adına insanlığı yönetmek için gönderildiği sözüdür. Tanrı gibi (ve) Tanrıdan olmuş Türk Bilge Kagan ${ }^{77}$ ifadesi bu durumu göstermektedir. Ayrıca yine Göktürk inancına göre üstte mavi gök, altta yağız yer yaratılmış, bu ikisi arasında da insanoğlu yaratılmıştır ${ }^{78}$. Bu insan oğlunun üzerine Bumin ve İstemi hükümdar olarak tahta oturmuşlardır. Kadim Türk telakkisini yansıtan Abidelere göre iş başına gelen Kaganın ilk işi, Türk halkının devletini ve yasalarını düzenlemek ve yasalara göre onları yönetmek olmuştur. Hükümdar olacak kişinin gök ve yerin yaradılışıyla beraber ele alınması hem hükümdarın hem de yönetme işinin ilahi düzenin bir parçası olduğunu bizlere göstermektedir. Evrenin temel parçalarını oluşturan gök ile yerin yaratılmasının hemen ardından insanın yaratılması, ardından da yönetilme meselesinin çözülmesi, devletin yaratılış ve kâinat tasavvurundaki yerini ve ehemmiyetini ortaya koymaktadır.

Türk devletinin karakteristik yapısında, Cihan Hâkimiyeti ülküsünde Tanrının kâinatı yaratma ve evren tasavvuru ile Kut anlayışı belirleyici rol oynamıştır. Herhangi birinin hükümdar olabilmesi için Tanrının Kut vermesi gerekmektedir ${ }^{79}$. Kut aldığına inanılan hükümdar toplumun sorunlarını çözerek, toplumu memnun ederek Kut sahibi olduğunu ispatlamak zorundadır. Başarılı hükümdarlar, Kut sahibi oldukları için Tanrının yeryüzündeki gölgesi olarak nitelendirilmişler ve bu sebepten dolayı Tanrının korumasında olduklarına inanmışlardır ${ }^{80}$. Hem Tanrıyı hem de halkı temsil eden hükümdar toplumsal varoluşun temel dayanağıdır. Toplumun güven ve huzur ortamında varlığını sürdürmesinin yanında halkının Tanrı nezdinde iyi bir yere sahip olmasını sağlayacak olan da $\mathrm{O}$ dur. En temel görevlerinden birisi de halkı birleştirmek ve isteğine uygun olarak bütün insanları göğün altında Türk devletinin idaresinde toplamaktır ${ }^{81}$.

Hükümdarın halk ile olan ilişkisi, devletle olan münasebetini ve yönetiminin sınırlarını da büyük ölçüde belirlemektedir. Hükümdar devletin temsilcisi olması nedeniyle onun özellikleri devletin ve bu devleti oluşturan halkın özellikleri olmalıdır. Hükümdarın her

76 Giraund, aynı eser, s. 108.

77 Kül Tigin, Güney 1, Ergin, aynı eser, s. 3.

78 Kül Tigin, Doğu 1; Bilge Kagan, Doğu 2, Doğu 3, Ergin, aynı eser, s. 9, 33.

79 Bicak, aynı eser, c. I, s. 79.

80 Roux, Türklerin ve Moğolların Eski Dini, s. 91.

81 Roux, aynı eser, s. 227. 
şeyden öte sahip olması gereken iki nitelik vardır bunlar, bilgelik ve savaşçılıktır ${ }^{82}$. Bu niteliklerden ilki olan bilgelik, Türk hükümdarınca ahlaki, dini, iktisadi ve sosyal değerler başta olmak üzere, toplumun düşünce ve eylemlerini yönlendiren bir yapıdır. Bu yapıda esas unsur Türk toplumunun Töresi ve gelenekleridir. Hükümdarın hareket noktasını, yetkilerinin hudutlarını bu unsurlar ile değerler silsilesi belirlemiştir.

Devletin hukuk mekanizmasının işlemesini sağlayan Töre ile devletin dâhili ve harici işleri görülmektedir. Törenin kapsamı halkın hak ve hürriyetleri, kanun, hukuk, hükümdarın etkileri ve vazifeleri cezai hükümleri içermektedir ${ }^{83}$. Devletin varlığı bu Töre diye adlandırılan hükümlerin uygulanmasına bağlıdır. Türk Töresinin sert, kesin ve değişmez maddeleri olmakla beraber, devrin şartlarına göre ilaveler yapılabilir, değiştirilip yeniden yorumlanabilirdi. Değiştirilemeyen maddeler bir nevi kanunların ruhunu belirleyen anayasa hükümleri gibiydi. Kutadgu Bilig'den anlaşıldığına göre Törenin değişmez esasları könilik (adalet), uzluk (iyilik, faydalılık), tüzlük (eşitlik) ve kişilik (insanlık, cihanşümullük) idi. Töre hükümleri hükümdar da dahil bütün toplum için bağlayıcıyd1 ${ }^{84}$.

Devlet ve vatandaşların kurumlar arasındaki ilişkilerini düzenleyen, yönetim erkinin sınırlarını belirleyen eski Türk kamu hukuku Türk idari yapısı ile doğrudan irtibatlı idi. Türkistan bozkırlarında cereyan eden ve at ile demirin temel unsurunu oluşturduğu Türk idari ve sosyal yapısının, kültürünün Göktürk öncesi dönemlerine dair kaynaklarda açık bilgiler bulunmamaktadır. Bu nedenle Göktürk cemiyet yapısı esas olarak alınmaktadır. Hareket noktasını oluşturan Orhun Abidelerine göre, Türk Bozkır Cemiyeti'nin yapısını şu şekilde tespit etmek mümkündür: Oguş (Aile), Urug (Aileler Birliği), Bod (Boy, Kabile), Bodun (Boylar Birliği), İl (El, Devlet, Bağımsız Topluluk, İmparatorluk). Bu yapının işleyişi Türk toplum hayatını düzenleyen kaidelerin oluşumu ve aile reisinden devlete kadar yönetim erklerinin fonksiyonları, hudutları açısından belirleyici unsur olmuştur ${ }^{85}$.

Eski Türk devlet geleneğinde hükümranlık Oğuz Han soyuna ait olduğundan bütün Türk hükümdarları kendilerini o soydan kabul ederlerdi. Halk da o hanedanın Oğuz Han soyundan geldiğine inanırdı. İslam öncesinde devlet başkanlığında Kut bu soyda tecelli ettiği gibi, İslam döneminde de bu hanedan telakkisine sadık kalındı. Nitekim Selçuklular güçlüyken hâkimiyet hakkına sahiptiler ve onlara diğer Türk boyları da tâbi idiler. Selçukluların gücü kalmayınca yani nasipleri tükenince hâkimiyet Osmanlılara geçmiştir ${ }^{86}$.

82 Giraund, aynı eser, s. 114-115.

83 Başer, aynı eser, s. 112-113.

84 Donuk, Eski Türklerde Devlet ve Teşkilat, s. 87, Dipnot 705.

85 Kafesoğlu, Türk Milli Kültürü, s. 227.

86 Niyazi, Türk Devlet Felsefesi, s. 45, 49; C. Brockelmann, İslâm Milletleri ve Devletleri Tarihi, çev. N. Çağatay, Ankara Üniversitesi İlahiyat Fakültesi Yayınları, Ankara 1954, s. 266; Kaşgarlı Mahmud, Divanü Lügati tTürk, I, s. 48, 106, 168; II, s. 10, 25, 238; III, s. 21, 123; Z. Gökalp, Türk Devletinin Tekâmülü, Ülkü Ocaklar1 Yayınları, Ankara 1976, s. 14-15; S. Çağatay, “İl, Ulus ve Yönetenler”, DTCF Cumhuriyetin 50. Yıldönümü Anma Kitabl, Ankara 1976, s. 286. 


\section{Eski Türk Devletlerinde Meclis (Toy, Kurultay) ve Hükümdarın Fonksiyonu}

Devlet idaresinin temelini oluşturan meclisler, Asya Hunlarından beri bilinmekte ve bütün büyük Türk devletlerinde farklı isimlerle de olsa mevcudiyetine rastlanmaktaydı. Belirli yer ve zamanlarda toplanan, sıkı protokol kurallarının uygulandığ konuşmasıyla çalışmalarına başlardı. Devletin en önemli kararlarının alınıp görüşüldüğü, Kagandan sonra devlet teşkilatında önemli bir yere sahip olan bu meclislerde devletin savaş açılıp açılmaması, harici problemleri, iktisadi, askeri, siyasi, kültürel gibi dahili tüm meseleleri gündeme getirilip görüşülerek karara bağlanırdı. Elçiler kabul edilir, hükümdarların kararları, devlet organlarının icraatları ve Törenin uygulanışı denetlenir, Kaganlık makamı boş ise yeni Kagan seçimi, tasdiki ve gerektiği takdirde Töreye yeni hükümlerin ilave edilmesi de gerçekleştirilirdi. Ayrıca ordu teftiş edilir, insan gücü saptanır, toplum hayatının önemli unsuru hayvan sayısı belirlenir ve Kaşgarlı Mahmud'un “Geniş elbise parçalanmaz, danışmakla gelişen bilgi ise bozuk ve kötü çıkmaz”, sözündeki gibi uygulamaya dönük sağlıklı ve doğru kararlar almak için ülke meselelerine dair genel müzakere yapılırdi ${ }^{87}$.

Eski Türk İl (el)'inin yani devletinin başında İlig, Elig, İllig denilen hükümdar bulunurdu, Bunlar genelde Tanhu, Han, Yabgu, Kagan (daha çok cihanşümullüğü ifade eder) gibi unvanlar kullanırlardı. Ayrıca İl-teber (Uygurlarda), Kül Erkin (Karluklarda) unvanları da görülmüştür. Belirli bir Boy’un başındaki şahsın unvanı olan "Bey” de, Kutadgu Bilig'de olduğu gibi sonraları hükümdarları ifade etmek için kullanılmıştır. Karahanlılarda devletin başında bulunan Hakana "Arslan Han", onun hâkimiyetinde bulunan ülkenin batısını yönetene de "Buğra Han” denirdi. Gaznelilerde hükümdar Mahmud'un halifeden aldığı çeşitli unvanlar arasında "Sultan"ın da bulunması Türk hükümdarlarının bir unvan daha kullanmalarına vesile olmuştur. Büyük Selçukluların en göz kamaştırıcı dönemlerinde (Melikşah-Sencer devirleri) merkezde bulunan büyük Hakana Es Sultanü'l-Azam denilmekte idi. Tuğrul Bey, Sultan unvanı almıştır. Zamanla Yabgu unvanı terkedilerek Melik unvanı benimsenmiştir ${ }^{88}$.

Otağ, Orgin (taht), Tuğ, Davul, Kotuz, yay eski Türklerde hükümdarlık alametleriydi. Zaman içerisinde ele geçirilen bölgeye içinde Örgin bulunan Kale-Saray inşa etmek de hâkimiyete işaret etmiştir. Tahtlar altından yapılmış ve "Altın Otağ” diye anılmıştır. Otağ’1 yıkmak hükümranlığa son vermek demekti ${ }^{89}$. Göktürkler ve Uygurlarda olduğu gibi Tuğ,

87 M. Mandaloğlu, "İslamiyetten Önce Türklerde Toplantı ve Törenler”, Türkiye Sosyal Araştırmalar Dergisi, sayı 6, 2012, s. 211-232; B. Ögel, Türklerde Devlet Anlayışı (13.Yüzyll Sonlarına Kadar), Başbakanlık Basım Evi, Ankara 1982, s. 73-94; DLT.; A. Pamir, “Orta-Asya Türk Hukukunda 'Töre‘ Kavramı”, Ankara Üniversitesi Hukuk Fakültesi Dergisi, c. LVIII, no. 2, s. 366-367; N. Akpınar, Büyük Hun Devletinden Osmanlı Devletine Kadar Türkler Devletlerinde Meclis, Mimar Sinan Güzel Sanatlar Üniversitesi, Yayınlanmamış Yüksek Lisans Tezi, İstanbul 2009, s. 8.

88 Niyazi, Türk Devlet Felsefesi, s. 71, 79-80; Genç, Karahanlı Devlet Teşkilatı, s. 78-82; Köymen, Alp Arslan ve Zamanı, s. 10.

89 A. Taşağıl, "Eski Türk İdaresi”, Tarih ve Medeniyet, sayı 58, 1999, s. 58; R. Özdamar, Íslamiyet Öncesi Türkler'de Hakimiyet Mefhumu, Fırat Üniversitesi Sosyal Bilimler Enstitüsü, Yayınlanmamış Yüksek Lisans Tezi, Elazı̆ 1997, s. 21-22. 
Altından Kurt Başlı Sancaktı. Kotuz ise Börk’e takılan küçük bir tutam yabani sığır yahut at kuyruğu kılı, tüyü idi. Eğer devlet kurucusu olarak kendisinin otoritesi kabul edilen ilk hükümdar değil de ölüm gibi çeşitli sebeplerle hükümdarlık makamı boşalmış ise, önce hukuki bakımdan tahta çıkması gereken şehzadeye hükümdarlık teklif edilir, şehzade alçak gönüllük göstererek üç kez bunu reddeder, nihayetinde kabul ederdi ${ }^{90}$. İslamlaşmayla birlikte hükümdarlığın halife tarafından tasdiki, ülkede okunan hutbelerde hükümdarın adının, unvan ve lâkablarının zikredilmesi, parada adının olması, hükümdarın başının üzerinde çetr (sırmalı kadifeden şemsiye), taht, tâc, tırâz (hükümdarın ad ve lâkablarının işlenmiş bulunduğu -sembolü olan renkte imal edilen- elbisenin adı), bayrak, nevbet hâkimiyet alameti idi. Türk Hükümdarı tahta çıkış töreninde yüzü batıya dönük vaziyette keçe veya halıya oturtularak veya kalkan üzerinde havaya kaldırılır, güneş yönünde dokuz kere döndürülürdü. Her dönüşte hanedan üyeleri, devlet erkânı, yerli ve yabancı davetliler saygıyla eğilirlerdi. Akabinde hükümdar ata bindirilerek dolaştırılırdı. Ayrıca Kagan seçilecek kişinin boğazı bir ipek şeritle iyice sıkıştırılarak kaç yıl hüküm süreceği ile ilgili soru sorulduğu, söylediği sözlerin millet tarafından dikkatlice dinlenip, tasdik edildiğine dair rivayetler bulunmaktadır ki, bunun Türk hükümdarlarının sınırsız salahiyetine sahip olmadığına delalet ettiği düşünülmüştür. Tahta çıkma töreni; genelde boylar yani güçler birlikteliği şeklinde kurulan Türk devletlerinde hükümdara kuruluş ruhu ve felsefesi ile devletin temel unsurlarını hatırlatması bakımından sembolik önem taşımıştır. Hükümdar, başarılı olabilmesi için Tanrının verdiği başlıca şu üç özelliği kendinde toplamalıydı: 1- Tanrı kendisine "yarlığ" vermeliydi. 2- Tanrı onu "Kut" ile donatmalıydı. 3- Onun kısmetli (ülüğli) olması gerekirdi ${ }^{91}$.

Kutadgu Bilig'e göre Türk Hükümdarı; Bilge, akıllı ve bilgili, cesaretli-kuvvetli ve kahraman olmalı, asil soydan gelmeli, dürüst ve fazilet sahibi olmalı, sözünde durmalı, hasis olmamalı, yumuşak huylu-alçak gönüllü-himmet ve haya sahibi, ihtiyatlı ve uyanık, aceleci değil sabırlı olmalı, zalim olmamalı, merhametli-şefkatli olmalı, yalancı olmamalı, siyasette mahir olmalı, inatçı olmamalı, temiz, takva sahibi, tatlı dilli-güler yüzlü olmalı, mağrur-kibirli olmamalı, tok gözlü, gönlü temiz-kalbi doğru, anlayışlı, misafirperver, nefsine hakim olmalı, harama el uzatmamalı, Tanrı'ya kulluk etmeli, içki içmemeli, kumar oynamamalı, fesattan uzak durmalı, kan dökmemeli, düşmanlık besleyip kin gütmemeli, kılıcı elden bırakmamalı, dünya malına değer vermemeli, dünyaya aldanmamalı, varlığının fani olduğunu unutmamalıdır ${ }^{92}$.

90 L. N. Gumilöv, Eski Türkler, çev. A. Batur, Selenge Yayınları, İstanbul 1999, s. 83.

91 A. Donuk, Eski Türklerde Devlet ve Teşkilatı, s. 163-166; A. Taşağıl, "Gök Türk Devlet Modeli”, I. Türk Tarihi Sempozyumu, Türklerde Devlet Bildiriler, ed. Hayrunnisa Alan, Ali Ahmetbeyoğlu, Uğur Demir, Adnan Baycar, Seçil Ofset, İstanbul 2108, s. 123; Köymen, Alp Arslan ve Zamanı, s. 10-27.

92 Donuk, Türk Hükümdarı, s. 9-27; N. Ağırnasl1, "Büyük Selçuklu Devlet Adamlarının Adâlete ve Refaha Dayalı Toplum Düzeni Oluşturma Gayretleri”, http://cahij.com/Makaleler/2070740253_112-122.pdf, s.114-116; A. Dilaçar, Kutadgu Bilig İncelemesi, TDK Yayınları, Ankara 1988, s. 108. 
$\mathrm{Bu}$ vasıfları taşıması gerektiğine inanılan hükümdardan beklenilen vazifeler ise şöyle idi; Barış ve sükûnu sağlamalı ve bunu yalnız Türk ülkesi ölçüsünde değil, dünya çapında gerçekleştirmeli; milleti için gündüz oturmadan, gece uyumadan hizmet etmeli ve vatanı müdafaa etmeli; memleketi tanzim ve idare etmeli; halkı düzene sokmalı; iyi kanunlar yapmalı, adaletle tatbik etmeli ve halkı korumalı; dağınık boyları toplayıp nüfusu çoğaltmalı; halkı çıplak ise giydirmeli, aç ise doyurmalı; yiyecek-içecek vermeli ve mal dağıtmalı; kuldan fakir adını kaldırmalı; halkın menfaatini düşünmeli ve Onlara şefkatle muamele etmeli; devlet idaresinde sadık, seçkin idare adamlarına görev vermeli; âlimleri himaye etmeli; kumandan olmalı, asker toplamalı, askeri memnun etmeli; kötüleri cezalandırmalı, iyileri korumalı; meclisi toplamalıdır ${ }^{93}$.

Selçuklulara kadar Türk devletlerindeki anlayışı yansıtan Kutadgu Bilig'de Yusuf Has Hacib, halkın hükümdardan esas beklentisini ve hükümdarın onlardan isteğini şu noktalarda toplamıştır:

- Memlekette, gümüş temiz kalsın, onun ayarını koru (para ayarının korunması, iktisadi istikrar),

- Halkı adil kanunlar ile idare et, birinin diğerine tahakküme kalkışmasına meydan verme, onları koru (adil kanun),

- Bütün yolları emin tut, yol kesici ve haydutların hepsini ortadan kaldır (asayiş),

- Halk hükümdarın emirlerine hürmet etmeli ve bu emir ne olursa olsun, onu derhal yerine getirmelidir,

- Hazine hakkını gözetmeli ve bunu vaktinde ödemelidir,

- Hükümdarın dostuna dost, düşmanına düşman olmalıdır.

Böylece Hükümdar halka karşı vazifesini yapmış olur, halk da hükümdarın hakkını ödemiş olur ${ }^{94}$.

Hükümdar taşıması gereken niteliklerinde zaaf göstermeye başlar, toplumun ve devleti oluşturan güçler birlikteliğinin beklentilerini karşılayamaz duruma düşer, ülkeyi felaketlere açık hale getirir ise hakimiyeti tartışmalı konuma gelir ve bu durumda Meclis devreye girerek hükümdarlığı sonlandırılırdı.

\section{Sonuç}

Türk kültürünün ve toplumunun zirve müessesesi olan devletin temelini hukuk ve adalet oluşturmuştur. Türk devletini Töre etrafında teşekkül etmiş bir anlayışın ürünü olarak değerlendirmek gerekmektedir. Hükümdarın Kut sahibi olması gerekliliği Töreye bağlı kalıp kalmaması ile ilişkilendirilmiş, Töreye bağlı olan hükümdar Kut sahibi sayılmış, Töreye uymayan hükümdarlığını yitirmiş hatta bazen katledilmiştir. Dolayısıyla hükümdarın Kut

93 Donuk, Türk Hükümdarl, s. 27-38.

94 K.B. Beyit: 5574-5583. 
sahipliğinin somut şartı devleti güçlendirmek, ayakta tutmak, halkın refah ve huzurunu temin etmek ise soyut şartı da devletin kuruluş ve işleyiş düzenini sağlayan Töreye bağlılık olmuştur. Hükümdarın sahip olması gereken bilgelik ve savaşçılık vasıfları da bu iki şartı yerine getirmeye matuf olarak karşımıza çıkmıştır.

Türk devletinde Kut verildiğine inanılan hükümdar kutsal addedilmemiştir. İlahi menşeili Kut daimî değildi. Asıl kutsal olan Töre idi. Hükümdar Kut sahipliğini ancak Töreye bağlı kalarak tesis edebilir ve sürdürebilirdi.

Hükümdarın kutsal olmamasının bir tezahürü olarak kurultay (meclis) müessesi ön plana çıkmıştır. Hükümdarın denetlenme vazifesi yanında devletin asli işlerinin de görüldüğü kurultay, Türk devletlerinde hükümdarın bir tanrı-kral yahut iktidarını tek başına kullanan despotik bir egemen haline gelmesi önündeki engel konumundaki en önemli yapıydı. Töreye uymayan hükümdarın ikaz edilmesi de meclisin uhdesindeydi. Bu nedenle hükümdarın Kut alması kâfi değildi, töreye sadık kalarak kut sahipliğinin isbat-1 vücut etmesi gerekmekteydi. Töreye sadık kalmamak adaletin zıttı olan zulmü getirir ki, bu da hükümdarın ve devletlilerin sınırlarının tayini bakımından önemli bir noktaydı.

Kut'unu yahut metafizik meşruiyetini yitirmemek için yasayı eşit tatbik etmek, adil olmak ve doğruluktan ayrılmamak Türk hükümdarlarının vazgeçilemez vasıfları arasında yer almıştır. Kanuna ve örfe bağlılık sayesindedir ki sırf güce bağlı bir zorbalık yerine hükümdarın meşru otoritesinden bahsetmek mümkün olmuştur. Kut ve Kut'un somut delili olarak kabul edebileceğimiz Töreye bağlılık, hükümdarın egemenliğinin kaynağını ve sınırını oluşturmuştur. İktidarını Töreye göre sürdürmek mecburiyetinde olan hükümdar bu temel kaideden ayrıldığı anda meşruiyetini kaybederdi. Devletin idari mekanizmasında yer alan yöneticiler de ülkede geçerli olan hukuka aykırı davranarak yetkilerini aştıklarında makam ve mevkilerinden uzaklaştırılırdı.

Türk devlet felsefesine göre meşruiyetini Töreden alan ve sadece kendi ülke sınırları dâhili için değil, cihanşümul sorumluluk yüklenen Türk hükümdarına sonsuz hâkimiyetyönetim yetkisi verilmemiş, dini değerler, kadim gelenekler ve yasalar ile yönetim gücü sınırlandırılmıştır. Adeta modern devlet teorisinde kuvvetler ayrılı̆̆ı marifetiyle tesis edilmeye çalışılan denetlenebilir bir devlet anlayışının erken dönem tezahürü olarak kabul edilebilecek bir tatbikat söz konusudur. Modern devletin yetkilerini ve görevlerini anayasada belirlemesi gibi Türk devlet geleneğinde de Töre ve yasalar marifetiyle hükümdarın iktidarının çerçevesi belirlenmiş ve denetlenebilir kılınmıştır. İslam öncesi ve sonrası Türk devletlerinin temel ilkeleri olan gelenek-töre-şeriat-yasa-akıl hükümdarlar başta olmak üzere devlet kurumlarının, idarecilerinin yetki ve güçlerinin hudutlarını belirleyen başlıca âmil olmuştur. 
Türk devletini sadece bir soy asabiyesine dayanan egemenlik tezahürlerinden ayıran ve bir Türk devlet felsefesinden bahsedilmesini mümkün kılan ve bu felsefe bağlamında bir fenomen olarak incelenmesini zaruri hale getiren de Töreye riayetin meşruiyetin doğrudan kaynağı olmasıydı. Zira Türk düşüncesi ve tarihi sürece göre devlet hükümdarın şahsi malı değildi. Sadece belli ölçülerde kullanmak kaydıyla hâkimiyet hakkı hükümdara aitti.

Türk devletinin dört temel unsuru olarak zikredilen istiklal, ülke, halk, Töre (kanun)den; töre harici diğer üç unsur herhangi bir siyasi organizasyonun devlet olarak incelenebilmesi için gereken asgari şartlardı. Ancak Türk devletinin alâmet-i fârikâsı töreye bağlılığıydı. Diğer üç unsur ise, töre üzerine inşa edilmiştir.

Nitekim İslâm öncesinde Töre olarak isimlendirilen metafizik meşruiyet kaynağı İslâm sonrası dönemde şer'i hükümler olarak karşımıza çıkmaktadır. Örfî uygulamaların Şer'i Hukukun izin vermesiyle tatbiki de Törenin bir uzantısı olarak değerlendirilebilir. Yine Töreye bağlılık fikrinin Türk devletinde yer etmişliği İslâmiyet sonrası dönemde ilahi hükümlere riayet fikrini kolaylaştırmış ve tatbikini mümkün kılmıştır. Denebilir ki İslamiyet öncesi dönemde Töre şeklinde tezahür eden hak, adalet ve hukuk fikri; İslamiyet sonrası dönemde İslâm'ın şer'̂̂ hükümlerine tahavvül etmiş ve egemenliğin sınırı ve şer'î hükümlere riayet meşruiyet kaynağı olarak görülmüştür.

Türk-İslam devletlerinde hükümdarların aslî vazifesi kanun yapmaktan ziyade kanunu adil uygulamaktır. Asli ahkâma herhangi bir müdahale söz konusu olmadan gündelik hayatı sevk ve idare için yapılacak düzenlemeler de hukuk ihtisası gerektirdiğinden bu konularda düzenleme yapma işi hukukçular tarafından icma yoluyla gerçekleştirilmiştir. Burada da hükümdarın hukuk marifetiyle sınırlandırılmasını müşahede etmek mümkündür. Yine İslamiyet öncesi dönemden Kurultaya benzer yapıların da Âlimler ve İhtiyarlar Meclisi yahut Divan-1 Saltanat isimlerinde Türk-İslam devletlerinde uygulandığı bilinmektedir. Hükümdar seçmekten, hükümdar emirlerini tartışmaya kadar pek çok yetkiyi haiz olan bu mekanizmaların varlığı da hükümdarın hâkimiyet sınırına işaret ettiği açıktır.

Türk devletleri hukuk felsefeleri, idari yapıları, uygulamaları ve evrensel anlayışlarıyla tarih boyu insanlığı etkilemişlerdir. Zira coğrafî olarak Çin, Roma gibi çok kuvvetli devlet organizasyonlarının çok yakınında ayakta kalmak ancak bir devlet marifetiyle mümkün olmuş ve bu yüzdendir ki devletsiz kalmayı ölmek olarak gören Türk insanı, devletin ebedmüddet yaşamasının temelinde eşit tatbik edilmesi gereken, İl'in kuruluş ve işleyiş düzenini ifade eden Törenin yattığına inanmıştır. Modern devlet teorisinde hukuk devleti ilkesi olarak karşımıza çıkan egemenin denetlenmesi gerekliliği fikri Türk devletinde Töreye bağlılık şeklinde tezahür etmiştir. 
Hülasa Türk devlet geleneğinin üzerine inşa edildiği Türk devlet felsefesi, devleti hükümdarın şahsında temsil etme anlayışı üzerine otursa da hükümdar İslamiyet öncesi ve sonrası dönemde bir sınırlandırmaya tâbi tutulmuştur. Bu sınırlandırma İslamiyet öncesi dönemde Töre, İslamiyet sonrası dönemde Şer'i Hukuk şeklinde tezahür etmiştir. Bu sınırlandırmanın ihlali Meclis (Kurultay) tarafından yasa ve gelenek açısından incelenmiş ve sınırların ihlal edildiği tespit edilmiş ise hükümdarlığın alınması yaptırımı uygulanmıştır. Bu adalet temelli devlet anlayışıdır ki Cihan Hâkimiyeti ülküsünü mümkün kılabilmiştir.

Hakem Değerlendirmesi: Dış bağımsız.

Çıkar Çatışması: Yazar çıkar çatışması bildirmemiştir.

Finansal Destek: Yazar bu çalışma için finansal destek almadığını beyan etmiştir.

Peer-review: Externally peer-reviewed.

Conflict of Interest: The author has no conflict of interest to declare.

Grant Support: The author declared that this study has received no financial support.

\section{Kaynakça/References}

Ağırnaslı, Nilay, "Büyük Selçuklu Devlet Adamlarının Adâlete ve Refaha Dayalı Toplum Düzeni Oluşturma Gayretleri”, http://cahij.com/Makaleler/2070740253_112-122.pdf, s.114-116.

Ahmetbeyoğlu, Ali, “Tuna Bulgar Hükümdarı Malamir (831-836) Han”, Prof. Dr. İsmail Aka Armağanı, Beta

Basım, ed. Nejdet Bilgi ve Mehmet Ersan, İzmir 1999, s. 65-68.

Ahmetbeyoğlu, Ali, Avrupa Hun İmparatorluğu, TTK Yayınları, Ankara 2001.

Akpınar, N., Büyük Hun Devletinden Osmanlı Devletine Kadar Türkler Devletlerinde Meclis, Mimar Sinan

Güzel Sanatlar Üniversitesi Sosyal Bilimler Enstitüsü, Yayınlanmamış Yüksek Lisans Tezi, İstanbul 2009.

Alföldi, A., “Türklerde Çifte Krallık”, II. Türk Tarih Kurultayı Zabıtları, İstanbul 1943, s. 507-519.

Arsal, S. Maksudi, Türk Tarihi ve Hukuk, İstanbul Üniversitesi Hukuk Fakültesi Yayınları, İstanbul 1947.

Arslan, Mahmut, "Eski Türk Devlet Anlayışı ve "Çifte Hükümdarlık” Meselesi”, Fırat Üniversitesi Tarih Metodolojisi ve Türk Tarihinin Meseleleri Kolokyumu Bildiriler, Fırat Üniversitesi Yayınları, Elazı̆̆ 1990, s. 223-242.

Aydın, M. Akif, “Türk Hukuk Tarihinde Devlet ve Hukuk”, I. Türk Tarihi Sempozyumu, Türklerde Devlet Bildiriler, ed. Hayrunnisa Alan, Ali Ahmetbeyoğlu, Uğur Demir, Adnan Baycar, Seçil Ofset, İstanbul 2018, s. 47-54.

Aydın, M. Akif, Türk Hukuk Tarihi, Beta Basım Yayın, İstanbul 2017.

Bang, W. - R. Rahmeti Arat, "Oğuz Kağan Destanı”, yay. haz. Osman Fikri Sertkaya, Makaleler, c. I, Türk Kültürü Araştırmaları Enstitüsü Yayınları, Ankara 1987, s. 605-672.

Başer, Sait, Kutadgu Bilig'de Kut ve Töre, İrfan Yayınları, İstanbul 2011.

Bıcak, Ayhan, Türk Düşüncesinin Kökenleri, c. I, Dergah Yayınları, İstanbul 2009.

Brockelmann, C., İslâm Milletleri ve Devletleri Tarihi, çev. N. Çağatay, Ankara Üniversitesi İlahiyat Fakültesi Yayınları, Ankara 1954. 
Caferoğlu, Ahmet, Eski Uygur Türkçesi Sözlüğü, Türk Dil Kurumu Yayınları, İstanbul 1968.

Cin, Halil - Ahmet Akgündüz, Türk Hukuk Tarihi, Selçuk Üniversitesi Basımevi, Konya 1989.

Çağatay, Saadet, “İl, Ulus ve Yönetenler”, DTCF. Cumhuriyetin 50. Yıldönümü Anma Kitabı, Ankara 1976, s. 281-308.

Çakır, A., Bozkır Kültür Çevresinde Sosyal Yapı ve Teşkilatlanma, Gazi Üniversitesi Sosyal Bilimler Enstitüsü, Yayınlanmamış Yüksek Lisans Tezi, Ankara 2007.

Çandarlığlu, Gülçin, Uygur Devletleri Tarihi ve Kültürü, Türk Dünyası Araştırmaları Vakfı Yayınları, İstanbul 2004.

Deer, Jozsef, “İstep Kültürü”, DTCFD, XII, Ankara 1954, s. 159-176.

Dilaçar, Agop, Kutadgu Bilig Incelemesi, TDK Yayınları, Ankara 1988.

Divitcioğlu, Sencer, Oğuz’dan Selçukluya Boy, Konat ve Devlet, Eren Yayıncılık, İstanbul 1994.

Donuk, Abdulkadir, “Türk Devletinde Hakimiyet Anlayışı”, Tarih Enstitüsü Dergisi, sayı X-XI, İstanbul 1979-1980, s. 29-56.

, Eski Türk Devletlerinde İdari-Askeri Unvan ve Terimler, Türk Dünyası Araştırmaları Vakfı Yayınları, İstanbul 1989. , Eski Türklerde Devlet ve Teşkilatı, Yayınlanmamış Doktora Tezi, İstanbul Üniversitesi 1978.

, Türk Hükümdarı, Türk Dünyası Araştırmaları Vakfı Yayınları, İstanbul1990.

Düzgün, Dilaver, “Divanü Lügati’t-Türk’te Sosyal Normları Karşılayan Kavramlar”, A.Ü. Türkiyat Araştırmaları Enstitüsü Dergisi, sayı 55, Ankara 2007, 201-215.

Ergan, Nevin Göngör, "Bozkır Türklerinde Töre ve Sosyal Kontrol”, Polis Bilimleri Dergisi, cilt I, sayı 3 , Ankara 1999, s. 18-19.

Ergin, Muharrem, Orhun Âbideleri, Boğaziçi Yayınları, İstanbul 2008.

Erkoç, H. İhsan, Eski Türklerde Devlet Teşkilâtı (Gök Türk Dönemi), Hacettepe Üniversitesi Sosyal Bilimler Enstitüsü, Yayınlanmamış Yüksek Lisans Tezi, Ankara 2008.

Genç, Reşat, Karahanlı Devlet Teşkilatı, TTK Yayınları, Ankara 2002.

Gökalp, Ziya, Türk Devletinin Tekâmülü, Ülkü Ocakları Yayınları, Ankara 1976.

Gömeç, S. Yağmur, “Türklerde Devlet ve Hâkimiyet Düşüncesi Üzerine Bir Değerlendirme”, I. Türk Tarihi Sempozyumu, Türklerde Devlet Bildiriler, ed. Hayrunnisa Alan, Ali Ahmetbeyoğlu, Uğur Demir, Adnan Baycar, Seçil Ofset, İstanbul 2108, s. 471-490.

, Türk Kültürünün Ana Hatları, Akçağ Yayınları, Ankara 2006. , "Kagan ve Katun”, DTCF Tarih Araştırmaları Dergisi, sayı 29, Ankara 1997, s. 81-90.

Gumilöv, Lev Nikolayevic, Eski Türkler, çev. A. Batur, Selenge Yayınları, İstanbul 1999.

Güngör, Erol, Tarihte Türkler, Ötüken Neşriyat, İstanbul 2003.

Hassan, Ümit, Eski Türk Toplumu Üzerine İncelemeler, Alan Yayınc1lık, İstanbul 2000.

Hocaoğlu, Durmuş, Türk Kozmolojisi, İstanbul Üniversitesi Sosyal Bilimler Enstitüsü, Basılmamış Doktora Tezi, İstanbul 1994.

İbn Fazlan, Seyahatname, haz. R. Şeşen, Bedir Yayınları, İstanbul 1995.

İnalcık, Halil, “Kutadgu Bilig'de Türk ve İran Siyaset ve Nazariye ve Gelenekleri”, Türk Kültürü Dergisi, Reşit Rahmeti Arat Iç̧in, say1 39, Türk Kültürünü Araştırma Enstitüsü, Ankara 1966, s. 259-271. 
Kafesoğlu, İbrahim, Kutatgu Bilig ve Kültür Tarihimizdeki Yeri, Kültür Bakanlı̆̆ı Yayınları, İstanbul 1970. , Türk Milli Kültürü, Ötüken Neşriyat, İstanbul 1997.

Kaşgarlı Mahmud, Divanü Lügati ’t-Türk, I-IV, çev. B. Atalay, Türk Dil Kurumu Yayınları, Ankara 1939-1941. Koca, Salim, “İdeal Bir Türk Hükümdarı ve Baş Komutan Olarak Oğuz Kağan (Oğuz Kağan’ın Türk Tarihi Bakımından Değerlendirmesi)", Büyük Selçuklu Devletinden Türkiye Selçuklu Devletine M. Altay Köymen Armağanı, ed. Mehmet Hacı Gökmen, Selçuk Üniversitesi Türkiyat Araştırmaları Enstitüsü Yayınlar1, Konya 2011, s. 75-120.

, "Eski Türklerde Sosyal ve Ekonomik Hayat", Türkler, ed. Hasan Celal Güzel, Kemal Çiçek, Salim Koca, cilt III, Yeni Türkiye Yayınları, Ankara 2002, s. 347-385.

Köymen, M. Altay, Alp Arslan ve Zamanı, II, A.Ü. Dil Tarih Coğrafya Fakültesi Yayınları, Ankara 1983.

Mandaloğlu, Mehmet, “İslamiyetten Önce Türklerde Toplantı ve Törenler”, Türkiye Sosyal Araştırmalar Dergisi, say1 6, Ankara 2012, s. 211-232.

Mesudî, Murûc ez-Zeheb, çev. A. Batur, Selenge Yayınları, İstanbul 2004.

Niyazi, Mehmet, Türk Devlet Felsefesi, Ötüken Neşriyat, İstanbul 2011.

Okandan, R. Galip, Umumi Amme Hukuku, İstanbul Üniversitesi Yayınları, İstanbul 1976.

Orkun, H. Nanık, Eski Türk Yazıtları, Irk Bitig, c. III, Türk Dil Kurumu Yayınları, İstanbul 1940.

Ögel, Bahaeddin, Türk Kültürünün Gelişme Çăgları, I, Milli Eğitim Basımevi, Ankara 1968. , Türk Mitolojisi, I, TTK Yayınları, Ankara 1971.

, Türklerde Devlet Anlayışı (13. Yüzyıl Sonlarına Kadar), Başbakanlık Basımevi, Ankara 1982.

Özdamar, Ramazan, İslamiyet Öncesi Türkler'de Hakimiyet Mefhumu, Fırat Üniversitesi Sosyal Bilimler Enstitüsü, Yayınlanmamış Yüksek Lisans Tezi, Elazı̆̆ 1997.

Pamir, Aybars, “Orta-Asya Türk Hukukunda 'Töre’ Kavramı”, Ankara Üniversitesi Hukuk Fakültesi Dergisi, c. LVIII, no. 2, Ankara 2009, s. 359-385.

Rasonyi, Laszlo, Tarihte Türklük, Türk Kültürünü Araştırma Enstitüsü, Ankara 1971.

Roux, J. Poul, Türklerin ve Moğolların Eski Dini, Kabalcı Yayınları, İstanbul 2002.

Şen, Hüseyin, Íslam Öncesi Türk İnanış ve Düşüncesinde Gök, İstanbul Üniversitesi Sosyal Bilimler Enstitüsü, Yayınlanmamış Yüksek Lisans Tezi, İstanbul 2014.

Şeşen, Ramazan, İslâm Coğrafyacılarına Göre Türkler ve Türk Ülkeleri, Türk Kültürü Araştırmaları Enstitüsü Yayınları, Ankara 1985.

Taşağıl, Ahmet, “Eski Türk İdaresi”, Tarih ve Medeniyet, sayı 58, İstanbul 1999, s. 58-62.

, “Gök Türk Devlet Modeli”, I. Türk Tarihi Sempozyumu, Türklerde Devlet Bildiriler, ed. Hayrunnisa

Alan, Ali Ahmetbeyoğlu, Uğur Demir, Adnan Baycar, Seçil Ofset, İstanbul 2108, s. 111-134.

, Gök-Türkler, Türk Tarih Kurumu Yayınları, Ankara 1995.

Turan, Osman, Selçuklu Tarihi ve Türk İslâm Medeniyeti, Turan Neşriyat Yurdu, İstanbul 1969. , Türk Cihân Hâkimiyeti Mefkûresi Tarihi, Ötüken Neşriyat, İstanbul 2006.

Uğurlu, Serdar - Kadir Yılmaz, “Türk Devlet Yönetme Geleneğinde Töre’den Örf’e Değişim”, Turkish Studies, say1 6/2, 2011, s. 949-972.

Yakut, Esra, "Eski Türklerde Hukuk”, Anadolu Üniversitesi Edebiyat Fakültesi Dergisi, cilt I, sayı 3, Ankara 2002, s. 401-426.

Yusuf Has Hacib, Kutadgu Bilig, çev. R. R. Arat, TTK Basımevi, Ankara 1985. 